\title{
ANALISA TINGKAT KEHANDALAN UNIQUE SELLING PROPORTION, eWOM DAN FACEBOOK AdS TERHADAP PEMBELIAN KOPI KEKINIAN MENGGUNAKAN METODE KRUSKAL WALLIS
}

\author{
${ }^{1}$ Devi Kumala, ${ }^{2}$ Tuwisna, ${ }^{3}$ Cut Ramadhaniati \\ 1,2,3 Universitas Muhammadiyah Aceh \\ ${ }^{1}$ devi.kumala@unmuha.ac.id
}

\begin{abstract}
ABSTRAK
Tujuan penelitian ini adalah untuk mengetahui Analisa Tingkat Kehandalan Unique selling proposition, e-WOM dan facebook ads terhadap keputusan pembelian minuman kopi kekinian Harvies Coffee Banda Aceh. Metode penelitian ini adalah kuantitatif, sampel sebanyak 96 responden. Hasil Uji t an uji F menunjukkan secara partial variabel unique selling proposition dan e-WOM berpengaruh signifikan terhadap variabel keputusan pembelian, variabel Facebook ads tidak berpengaruh signifikan terhadap keputuan pembelian, namun berpengaruh positif. Secara simultan seluruh variabel independen berpengaruh signifikan terhadap variabel dependen. Nilai koefisien korelasi (R) sebesar 0,764, Nilai koefisien determinasi (Adjust R Square) sebesar 0,570. Unique selling proposition, e-wom dan Facebook ads berpengaruh terhadap keputusan pembelian, namun e-WOM memiliki pengaruh yang lebih besar, sehingga jika e-WOM ditingkatkan secara positif maka akan berdampak positif pada Keputusan pembelian minuman kopi kekinian Harvies Coffee Banda Aceh.
\end{abstract}

Kata Kunci: Unique Selling Proposition, e-WOM, Facebook Ads dan Keputusan Pembelian

\begin{abstract}
The purpose of this research was to determine the influence of unique selling proposition strategy, e-WOM and Facebook ads on purchase decision of the contemporary Harvies Coffee's coffee drink, Banda Aceh. This research method is quantitative with total of 96 costumers participated as respondent. The $\mathrm{t}$ test and $\mathrm{F}$ test shows that partially the unique selling proposition and e-WOM variables have a significant effect on the purchase decision variable, the Facebook ads variable does not have a significant effect on purchase decision, but has a positive effect. Simultaneously, all independent variables have a significant effect on the dependent variable. The value of the correlation coefficient $(\mathrm{R})$ is 0.764 , the value of the coefficient of determination (Adjust $\mathrm{R}$ Square) is 0.570. Unique selling proposition, e-WOM and Facebook ads have an effect on purchase decision, but e-WOM has a greater influence, so that if e-WOM is increased positively it will have a positive impact on the decision to purchase the contemporary Harvies Coffee's coffee drink, Banda Aceh
\end{abstract}

Keyword: Unique Selling Proposition, e-WOM, Facebook Ads dan Keputusan Pembelian 


\section{PENDAHULUAN}

Seiring perkembangan tegnologi yang semakin canggih di mana segala sesuatu menjadi serba digital, banyak kegiatan semakin mudah dijalankan, termasuk kegiatan pemasaran. Beberapa strategi pemasaran yang sebelumnya dijalankan dengan pola manual mulai beralih ke cara digital, ini menjadi sarana bagi konsumen memperoleh informasi sebagai pertimbangan sebelum melakukan pembelian. Strategi proposisi penjualan unik (Unique Selling Proposition) seperti perbedaan menonjol pada suatu produk harus benar-benar diperhatikan, dikarenakan WOM terkait suatu produk kini dapat diekspresikan di media elektronik, sehingga memungkinkan pengguna lain turut merespon atau membicarakan produk tersebut. Selain itu, produk yang sebelumnya dipromosikan menggunakan banner, pamphlet, brosur/selebaran, kini beralih pada iklan online melalui beberapa platform digital, di antaranya iklan media sosial seperti Facebook Ads, yang lebih efektif bagi siapapun yang terjangkau iklan untuk berinteraksi dengan penjual melalui jenis tombol tanggapan yang disediakan atau via media lainnya (yang ada dalam ekosistem e-marketing).

Harvies Coffee sebagai pelopor usaha minuman kopi kekinian di Kota Banda Aceh pada tahun 2014 ini menjadi salah satu usaha di bidangnya yang masih terus berkembang hingga sekarang. Konsumennya yang didominasi milenial aktif bersosial media membuat Harvies Coffee terus berkreasi, berinovasi, menciptakan keunikan, kelebihan dan perbedaan pada produknya hingga menghasilkan beberapa produk seperti Choco Belgian, Kopi Belgian, Kopi Almond, Kopi Nona, Kopi Kampung, Kopi Cream Cheese, Kopi Pokat, Kopi Greentea Cheese, Kopi Kakek. Produk Kopi Nona, Kopi Belgian, dan varian cheese menjadi produk yang terjual paling banyak (best seller), sehingga paling sering dibicarakan oleh konsumennya di media elektronik, seperti Facebook/Instagram story, whatsaap story, dan media sosial pribadi lainnya. Pada dasarnya ini merupakan strategi Harvies Coffee supaya konsumen memutuskan untuk membeli produknya. 


\section{Million audience reached}

by Facebook Ads

in Percentege

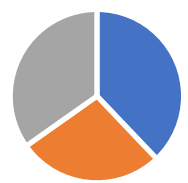

- Adult Aged 13+ $\quad$ Female $\square$ Male

Grafik 1. Jangkauan Facebook Ads

Sumber: websindo.com, 2019.

Grafik websindo (2019) di atas, menunjukkan ada 130 juta pengguna Facebook dapat dijangkau oleh iklan Facebook di Indonesia, 61\% pengguna berumur diatas 13 tahun, adapun $44 \%$ jangkauannya adalah wanita, dan $56 \%$ sisanya pengguna pria. Facebook Ads menjadi opsi bagi banyak usaha sekarang ini untuk digunakanan sebagai media iklan online, termasuk salah satu usaha yang menjadi penggunanya yaitu Harvies Coffee.

\section{TEORI}

\section{Keputusan Pembelian}

Dalam istilah umum, membuat keputusan adalah penyeleksian tindakan dari dua atau lebih pilihan alternatif menurut Schiffman dan Kanuk (2004) dalam Ivan Sindunata (2018). Dengan kata lain, keputusan dapat dibuat hanya jika ada beberapa alternatif yang dipilih. Apabila alternatif pilihan tidak ada maka tindakan yang dilakukan tanpa adanya pilihan tersebut tidak dapat dikatakan membuat keputusan.

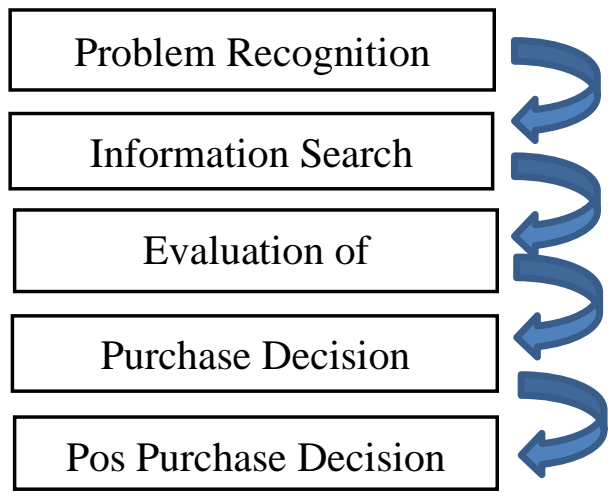

Gambar 1. Tahap Pembelian Oleh Konsumen. Sumber: (Kotler, 2012) 
Menurut Kotler (2007:214) dalam (Baransano, 2015) faktor-faktor yang mempengaruhi perilaku konsumen adalah budaya, sosial, pribadi, psikologis. Faktorfaktor tersebut harus diperhitungkan untuk mengetahui seberapa jauh dapat mempengaruhi pembelian konsumen.

Indikator keputusan pembelian konsumen meliputi:

1. Minat transaksional, kecenderungan konsumen untuk melakukan pembelian yang tedorong oleh keinginan mendapatkan produk.

2. Minat refrensial, kecenderungan konsumen untuk merekomendasikan produk kepada orang lain.

3. Minat preferensial, kecenderungan konsumen untuk lebih menyukai sebuah produk dibandingkan produk lainnya.

4. Minat ekploratif, kecenderungan konsumen untuk meningkatkan frekuensi pembelian maupun menambah jenis produk yang dibeli dari sebuah merek tertentu, Djimantoro \& Gunawan (2020).

\section{Unique Selling Proposition}

Unique Selling Proposition (USP) merupakan strategi kreatif yang sangat penting untuk dilakukan pada strategi pemasaran saat ini, dan menjadi langkah strategis dalam merumuskan brand differentiation sebagai upaya mengomunikasikan merek yang pada akhirnya akan meningkatkan citra merek (Wijaya, 2013 yang dikutip dari Puspita, 2020). Definisi untuk proposisi Penjualan Unik yang dikutip dari (Nganga, 2017) adalah:

"Berisi satu fitur produk yang paling menonjol sebagai perbedaan dari pesaing, dan biasanya merupakan fitur yang memberikan manfaat unik bagi konsumen".

The chartered institute of marketing (2009) menyatakan bahwa USP adalah salah satu alat utama pemasaran yang telah teruji oleh waktu. Felix dkk. (2012) mempelajari bagaimana membuat USP bermanfaat bagi pengiklan dan konsumen. Mereka mendefinisikan USP sebagai cara yang secara dramatis meningkatkan posisi dan daya jual perusahaan dan produk dengan mencapai tujuan berikut:

1. Unique: Hal ini membuat produk berbeda dengan yang lain.

2. Selling: Mengajak pelanggan untuk membeli produk yang ditawarkan.

3. Proposition: Proposal atau usulan untuk diterima. 
Unique Selling Propostion menjadi strategi penting karena beberapa faktor yang disebabkan oleh ciri utama dari Unique Selling Proposition seperti tuntutan untuk memperkenalkan perbedaan penting yang membuat suatu produk yang unik, lalu mengembangkan suatu klaim periklanan hingga para pesaing tidak dapat memilih atau tidak dapat memilih pilihan.

Yongge Niu dan Cheng Lu Wang (2016) dalam tarman Hidayat (2019), telah memperbarui konsep Unique Selling Proposition (USP) dari Reeves karena dinilai memiliki keterbatasan kekurangan. Mereka sepakat bahwa pernyataan manfaat dari USP adalah sebagai berikut:

1. Favorability (Menguntungkan), USP harus menguntungkan bagi pembeli potensial.

2. Believability (Dapat dipercaya), pernyataan manfaat dalam periklanan harus kredibel dan dapat dipercaya.

3. Distinctiveness (berbeda dari penawaran pesaing), USP harus unik dan khas dari penawaran pesaing,

4. Compatibility (Bermakna dan sesuai dengan harapan), Bermakna dan sesuai dengan harapan konsumen

5. Attractiveness (memiliki daya tarik), Manfaat yang di klaim dalam iklan harus menarik bagi calon konsumen.

\section{Electronic Word of Mouth (e-WOM)}

e-WOM mempunyai definisi sebagai sebuah media komunikasi untuk saling berbagi informasi mengenai suatu produk atau jasa yang telah dikonsumsi antar konsumen yang tidak saling mengenal dan bertemu sebelumnya (Gruen, 2006) dalam Ivan Sindunata (2018). Menurut Sen dan Leman (2008) dalam Ivan Sindunata (2018) mengungkapkan bahwa karakteristik utama dari e-WOM adalah bahwa sumber informasi bersifat independen. Hal ini dapat diartikan bahwa sumber informasi e-WOM tidak terikat dengan sebuah perusahaan tertentu dan tidak menguntungkan perusahaan manapun. Oleh karena proses komunikasi melalui e-WOM lebih dipercayai daripada sumber informasi yang berasal dari perusahaan. 
Hennig-Thurau dkk dalam (Mahgpiroh, 2017) merefleksikan Electronic Word-ofMouth (EWOM) melalui 8 dimensi, yaitu:

1. Venting Negative Feelings, motif venting negative feelings merupakan keinginan mengungkapkan ketidakpuasan konsumen terhadap produk atau perusahaan.

2. Concern for Others, merupakan keinginan tulus untumembantu konsumen lain terkait keputusan pembelian mereka, untuk menyelamatkan mereka dari pengalaman negatif, atau keduanya.

3. Helping the Company adalah keinginan konsumen membantu perusahaan.

4. Social Benefits, motif ini merupakan keinginan berbagi informasi dan berinteraksi dengan lingkungan sosial.

5. Advise seeking, motif untuk mencari saran dan rekomendasi dari konsumen lain.

6. Extraversion/Positive Self-Enchancement, dorongan dalam diri seseorang terhadap pengakuan positif dari orang lain.

Menurut Yang, Zhang, Wu, dan Xu dalam (Djimantoro \& Gunawan, 2020) menjelaskan bahwa e-WOM adalah komunikasi verbal antar personal antara kelompok yang tidak masuk dalam satu komunitas (terpisah) dan bukan untuk tujuan komersial. Menurut Sahin, Gulmez, dan Ersoy (2019, p. 16), e-WOM didasarkan pada, yaitu:

1. Berbagi informasi, kegiatan membagikan informasi di media sosial atau media lainnya seperti Whatsapp, Line, Instagram, dan lainnya.

2. Kepercayaan terhadap informasi, berhubungan dengan tingkat kepercayaan konsumen sebagai penerima informasi yang didapatkan dari berbagai media elektronik.

3. Daya tarik informasi, seberapa menarik sebuah informasi sesuai dengan penilaian penerima informasi di internet atau media sosial, dan diukur.

\section{Facebook Ads}

Facebook didefinisikan sebagai salah satu jenis website yang memiliki fasilitas bagi penggunanya untuk membangun jejaring pertemanan melalui internet. Selain membangun hubungan, Facebook dapat saling berbagi informasi, foto, video, dan informasi produk bisnis. 
Iklan facebook atau facebook ads adalah fitur yang ditawarkan oleh facebook untuk mempromosikan atau mengiklankan suatu fan page yang sebelumnya sudah dibuat oleh pengguna facebook dengan jangkauan yang berbeda dan dapat diatur oleh pemasang iklan tersebut.

Facebook Ads merupakan sebuah fitur yang disediakan oleh Facebook untuk para pebisnis online untuk menawarkan atau mengiklankan jualan mereka. Juga digunakan oleh brand, komunitas, public figure, partai politik, panitia seminar, konser musik serta siapapun yang ingin mengenalkan produk atau jasanya melalui Facebook Ads (Suryadin, 2018).

Ada cukup banyak keuntungan yang akan didapatkan jika beriklan menggunakan Facebook Ads.

1. Facebook Ads untuk Branding

2. Bisa Menampilkan Iklan Keapada Audience yang Spesifik

3. Berjualan Kepada Komunitas

4. Beriklan dengan Gambar atau Video

Berdasarkan tinjauan ekstensif literatur terkait, ditemukan bahwa variabel terkait periklanan Facebook dipengaruhi oleh tiga karakteristik utama: hiburan, interaktivitas, dan keinformatifan. Variabel-variabel tersebut kemudian digunakan sebagai parameter penelitian ini (Ashmawy, 2014 dalam Bagas Julianto, 2017).

1. Hiburan, variabel hiburan membuat keadaan pikiran yang mengangkat semangat terhadap iklan dan bahkan dapat membuat minat awal untuk iklan

2. Interaktivitas, respon langsung yang disebabkan oleh tindakan yang diambil oleh konsumen untuk memenuhi kebutuhan dan keinginan mereka

3. Informativeness, salah satu bagian fundamental dari periklanan yang menimbulkan pengaruh besar dalam mempengaruhi dan membentuk niat beli konsumen adalah informasi yang disampaikan

\section{METODE}

Penelitian ini adalah penelitian kuantitatif yaitu metode penelitian yang berdasarkan pada filsafat positivisme, digunakan untuk meneliti pada popolasi dan sampel tertentu, teknik pengambilan sampel biasanya merupakan pengumpulan data menggunakan instrument 
penelitian, analisis data bersifat kuantitatif atau statistik dengan tujuan menguji hipotesis yang telah ditetapkan.

Skala pengukuran yang digunakan dalam penelitian ini adalah skala likert.

Tabel 1. Skala Likert

\begin{tabular}{|c|c|}
\hline Keterangan (Pilihan) & Skor \\
\hline Sangat tidak setuju & 1 \\
\hline Tidak setuju & 2 \\
\hline Kurang setuju & 3 \\
\hline Setuju & 4 \\
\hline Sangat setuju & 5 \\
\hline
\end{tabular}

Sumber: (Sekaran \& Bougie, 2017)

\section{Definisi Operasional Variabel}

Tabel 2. Definisi Operasional Variabel

\begin{tabular}{|c|c|c|c|c|c|c|}
\hline $\begin{array}{c}\text { No } \\
\text {. }\end{array}$ & Variabel & Devinisi Variabel & Indikator & $\begin{array}{c}\text { Ukura } \\
\text { n }\end{array}$ & Skala & Item \\
\hline \multicolumn{7}{|c|}{ Variabel Dependen } \\
\hline \multirow{4}{*}{1} & \multirow{4}{*}{$\begin{array}{l}\text { Keputusan } \\
\text { Pembelian }\end{array}$} & \multirow{4}{*}{\begin{tabular}{|lr} 
Keputusan & pembelian \\
adalah & pengambilan \\
keputusan & oleh \\
konsumen & untuk \\
melakukan pembelian & pembatu produk diawali \\
suatu & oleh adanya kesadaran \\
atas ran & pemenuhan \\
kebutuhan dan keinginan \\
(Jason \\
2020) Djimantoro,
\end{tabular}} & $\begin{array}{c}\text { Minat } \\
\text { transaksional }\end{array}$ & $1-5$ & $\begin{array}{c}\text { Liker } \\
t\end{array}$ & A1 \\
\hline & & & $\begin{array}{c}\text { Minat } \\
\text { refrensial }\end{array}$ & $1-5$ & $\begin{array}{c}\text { Liker } \\
\mathrm{t}\end{array}$ & $\mathrm{A} 2$ \\
\hline & & & $\begin{array}{c}\text { Minat } \\
\text { preferensial }\end{array}$ & $1-5$ & $\begin{array}{c}\text { Liker } \\
\mathrm{t}\end{array}$ & A3 \\
\hline & & & $\begin{array}{c}\text { Minat } \\
\text { ekploratif }\end{array}$ & $1-5$ & $\begin{array}{c}\text { Liker } \\
\mathrm{t}\end{array}$ & A4 \\
\hline $\begin{array}{c}\text { No } \\
\text {. }\end{array}$ & Variabel & Devinisi Variabel & Indikator & $\begin{array}{c}\text { Ukura } \\
\text { n }\end{array}$ & $\begin{array}{c}\text { Skal } \\
\text { a }\end{array}$ & Item \\
\hline \multicolumn{7}{|c|}{ Variable Independen } \\
\hline \multirow{3}{*}{2} & \multirow{3}{*}{$\begin{array}{c}\text { Unique } \\
\text { Selling } \\
\text { Propositio } \\
\text { n }\end{array}$} & \multirow{3}{*}{$\begin{array}{l}\text { Strategi Unique Selling } \\
\text { Proposition merupakan } \\
\text { suatu teknik kreatif yang } \\
\text { optimum. Hal ini } \\
\text { disebabkan karena } \\
\text { strategi tersebut dapat } \\
\text { memberikan alasan } \\
\text { pembeda yang sangat } \\
\text { jelas kepada konsumen } \\
\text { untuk memilih produk } \\
\text { pengiklan dibandingkan } \\
\text { penawaran yang }\end{array}$} & $\begin{array}{c}\text { Favorability } \\
\text { (Keuntungan } \\
\text { yang } \\
\text { ditawarkan } \\
\text { jelas) } \\
\end{array}$ & $1-5$ & $\underset{t}{\text { Liker }}$ & B1 \\
\hline & & & $\begin{array}{c}\text { Believability } \\
\text { (Kualitas } \\
\text { yang } \\
\text { terjamin) }\end{array}$ & $1-5$ & $\begin{array}{c}\text { Liker } \\
\mathrm{t}\end{array}$ & $\mathrm{B} 2$ \\
\hline & & & $\begin{array}{c}\text { Distinctivene } \\
\text { ss (Inovasi } \\
\text { yang } \\
\text { dilakukan) }\end{array}$ & $1-5$ & $\begin{array}{c}\text { Liker } \\
\mathrm{t}\end{array}$ & B3 \\
\hline
\end{tabular}


Volume 1 No. 1. Januari - Juni 2021

DOI : https://doi.org/10.37598/jbidig.v1i1.1/1095

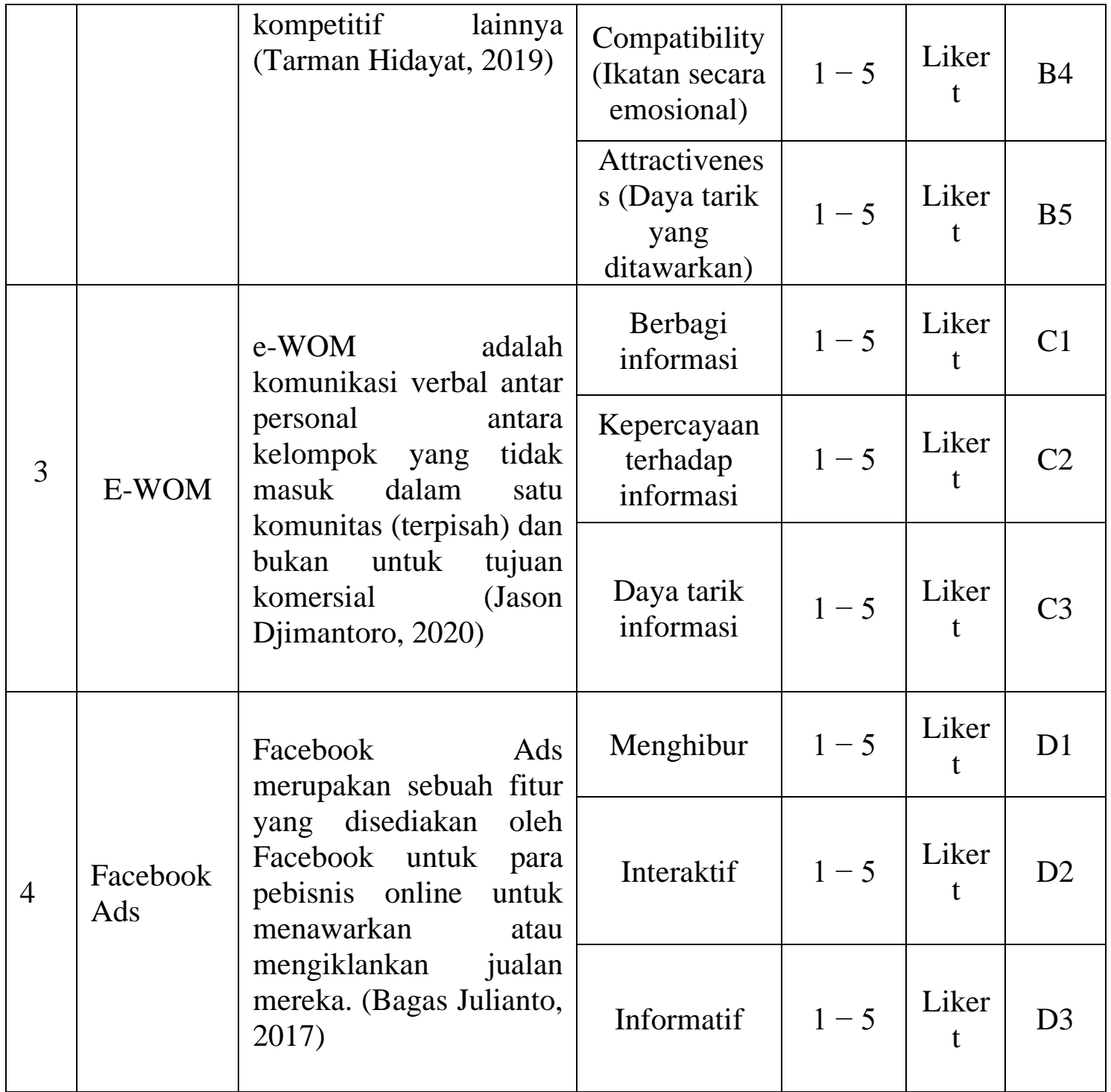

\section{DISKUSI DAN HASIL}

\section{Uji Validitas Instrumen}

Semua pernyataan mempunyai nilai korelasi di atas nilai kritis 5\% yaitu 0,202 sehingga pernyataan-pernyataan dalam instrumen penelitian ini adalah signifikan dan memiliki validitas. 
Tabel 3. Uji Validitas

\begin{tabular}{|c|c|c|c|c|c|}
\hline No & Pertanyaan & Variabel & $\begin{array}{c}\text { Koefisien } \\
\text { korelasi }\end{array}$ & $\begin{array}{c}\text { Nilai } \\
\text { kritis 5\% } \\
(n=96)\end{array}$ & Keterangan \\
\hline 1 & A1 & \multirow{4}{*}{ Y } & 0,620 & 0,202 & Valid \\
\hline 2 & A2 & & 0,642 & 0,202 & Valid \\
\hline 3 & A3 & & 0,674 & 0,202 & Valid \\
\hline 4 & A4 & & 0,592 & 0,202 & Valid \\
\hline 5 & B1 & \multirow{5}{*}{$\mathrm{X} 1$} & 0,656 & 0,202 & Valid \\
\hline 6 & B2 & & 0,717 & 0,202 & Valid \\
\hline 7 & B3 & & 0,678 & 0,202 & Valid \\
\hline 8 & B4 & & 0,756 & 0,202 & Valid \\
\hline 9 & B5 & & 0,735 & 0,202 & Valid \\
\hline 10 & $\mathrm{C} 1$ & \multirow{3}{*}{$\mathrm{X} 2$} & 0,670 & 0,202 & Valid \\
\hline 11 & $\mathrm{C} 2$ & & 0,784 & 0,202 & Valid \\
\hline 12 & $\mathrm{C} 3$ & & 0,830 & 0,202 & Valid \\
\hline 13 & D1 & \multirow{3}{*}{ X3 } & 0,781 & 0,202 & Valid \\
\hline 14 & D2 & & 0,838 & 0,202 & Valid \\
\hline 15 & D3 & & 0,744 & 0,202 & Valid \\
\hline
\end{tabular}

\section{Uji Reliabilitas Instrumen}

Pengujian reliabilitas dilakukan dengan internal consistency atau derajat ketepatan jawaban. Untuk pengujian ini digunakan statistical packaged for social sciences (SPSS) versi 25. Setelah melakukan pengujian reliabilitas untuk mengetahui konsistensi hasil sebuah jawaban tentang tanggapan responden.

Tabel 4. Uji Reliabilitas

\begin{tabular}{|c|l|c|c|c|}
\hline No & \multicolumn{1}{|c|}{ Variabel } & $\begin{array}{c}\text { Item } \\
\text { Variabel }\end{array}$ & $\begin{array}{c}\text { Nilai Cronbach } \\
\text { Alpha }\end{array}$ & Kehand \\
\hline 1 & Keputusan Pembelian (Y) & 4 & 0,811 & Hand: \\
\hline 2 & Unique Selling Proposition (X1) & 5 & 0,873 & Hand: \\
\hline 3 & E-Wom (X2) & 3 & 0,875 & Hand: \\
\hline 4 & Facebook Ads (X3) & 3 & 0,891 & Hand: \\
\hline
\end{tabular}

hasil pengujian variabel Keputusan Pembelian, Unique Selling Proposition, e-WOM dan Facebook Ads seluruhnya adalah reliabel karena melebihi dari 0,60.

\section{Uji Asumsi Klasik}

Uji Normalitas

Untuk pengujian normalitas data, dalam penelitian ini hanya akan dideteksi melalui analisis grafik yang dihasilkan melalui perhitungan regresi dengan SPSS versi 25. Data yang normal ditandai dengan sebaran titik-titik data diseputar garis diagonal. Hasil pengujian normalitas data dapat dilihat pada gambar 3: 


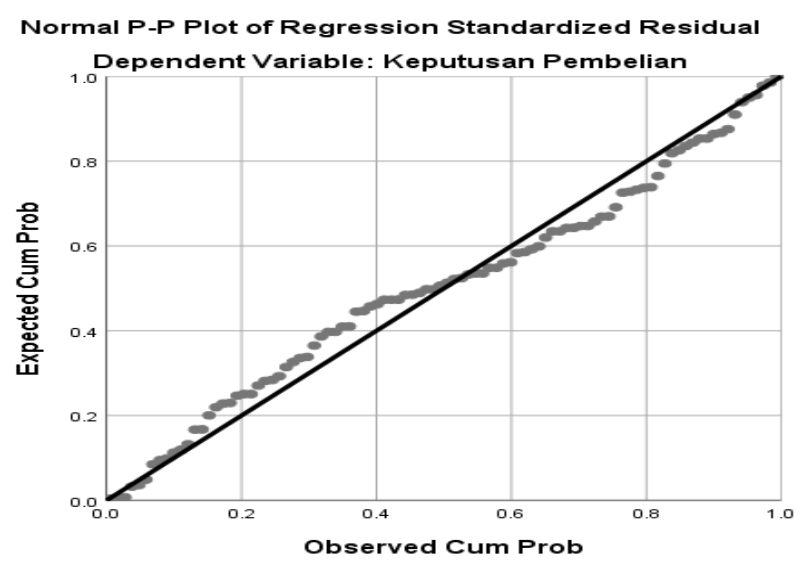

Gambar 3. Uji Normalitas

Dari grafik diatas terlihat titik-titik menyebar disekitar garis diagonal, serta penyebarannya mengikuti arah garis diagonal. Maka model regresi layak dipakai untuk memprediksi keputusan pembelian berdasarkan masukan variabel independent.

Uji Multikolinieritas

Uji multikolinieritas bertujuan untuk menguji apakah pada model regresi ditentukan adanya korelasi antar variable bebas. Jika terjadi korelasi, maka terdapat masalah multikolinieritas. Pada model regresi yang baik tidak terjadi korelasi di antara variable independen. Untuk uji multikolinieritas pada penelitian ini adalah dengan melihat nilai Variance Inflation Factor (VIF). Hasil uji multikolinieritas yang diuji dengan SPSS versi 24 ini dapat dilihat pada tabel berikut:

Tabel 5. Uji Multikolinieritas

\begin{tabular}{|l|c|c|c|}
\hline \multicolumn{1}{|c|}{ Variabel Bebas } & Toleransi & VIF & Keterangan \\
\hline Unique Selling Proposition (X1) & 0,435 & 2,300 & Non Multikolinieritas \\
\hline e-WOM (X2) & 0,330 & 3,027 & Non Multikolinieritas \\
\hline Facebook Ads (X3) & 0,503 & 1,987 & Non Multikolinieritas \\
\hline \hline
\end{tabular}

Tabel menunjukkan bahwa tidak ada satu variabel independen yang memiliki nilai toleransi yang kurang dari 0,10, berarti tidak ada korelasi antara variable independen. Hasil Variance Inflation Factor (VIF) juga menunjukkan hal yang sama tidak ada satu variabel independen yang memiliki nilai VIF lebih dari 10. Jadi dapat disimpulkan bahwa tidak ada multikolinieritas antar variabel independen dalam model regresi penelitian ini. 
Uji Heterokedastisitas

Uji heterokedastisitas bertujuan untukmenguji apakah dalam sebuah regresi terjadi ketidaksamaan varian dari residual pada satu pengamatan ke pengamatan yang lain. Jika varian dari residual satu pengamatan ke pengamatan yang lain tetap, maka disebut homoskedastisitas, dan jika varian berbeda disebut dengan heterokedastisitas. Berdasarkan hasil uji menggunakan SPPS versi 25 dapat dilihat:

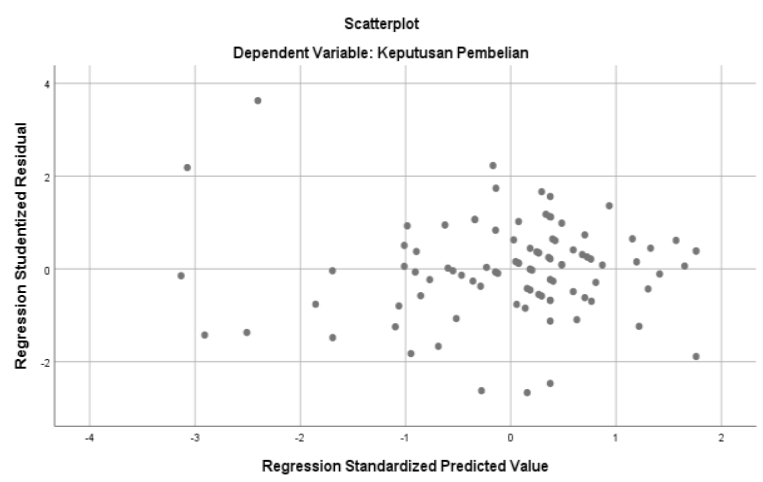

Uji heterokedastisitas terlihat titik-titik menyebar secara acak, tidak membentuk sebuah pola tertentu yang jelas, serta tersebar baik diatas maupun di bawah angka 0 pada sumbu Y. Hal ini berarti tidak terjadi heterokedastisitas.

\section{Analisis Deskriptif}

Penelitian ini mengamati tiga variable bebas (independent variable) yaitu variabel Unique Selling Proposition (X1), variabel e-WOM (X2) dan Facebook Ads (X3), juga mengamati satu variabel terikat (dependent vaiable) yaitu Keputusan Pembelian (Y).

\section{Pengujian Hipotesis}

Hipotesis menyatakan bahwa factor-faktor Unique Selling Proposition (X1), eWOM (X2) dan Facebook Ads (X3) berpengaruh terhadap Keputusan Pembelian (Y) minuman kopi kekinian harvies Coffee Banda Aceh.

Tabel 6. Koefisien Regresi

\begin{tabular}{|l|c|c|c|c|c|}
\hline \multicolumn{1}{|c|}{ Variabel } & $\mathbf{B}$ & Std Error & $\mathbf{T}_{\text {hitung }}$ & $\mathbf{T}_{\text {tabel }}$ & Sig. \\
\hline Konstanta & 0,241 & 0,306 & 0,788 & 1,665 & 0,433 \\
\hline Unique Selling Proposition (X1) & 0,359 & 0,112 & 3,220 & 1,665 & 0,002 \\
\hline e-WOM (X2) & 0,425 & 0,131 & 3,256 & 1,665 & 0,002 \\
\hline Facebook Ads (X3) & 0,125 & 0,086 & 1,450 & 1,665 & 0,150 \\
\hline
\end{tabular}

